\title{
Analysis of the Long-Term Outcome in Open Carpal Tunnel Release Surgeries with and without External Neurolysis of Median Nerve, Using Boston Carpal Tunnel Questionnaire (BCTQ)-Hindi Version
}

\author{
Sanjeev Pattankar ${ }^{1}$ Rohan Roy ${ }^{1}$ Anshu Warade ${ }^{1} \quad$ Ketan Desai $^{1}$
}

1Department of Neurosurgery \& Gamma Knife Radiosurgery, P D Hinduja Hospital \& MRC, Mumbai, India
Address for correspondence Ketan Desai, MS, MCh, Department of Neurosurgery, P D Hinduja Hospital \& MRC, Veer Savarkar Marg, Mahim, Mumbai 400016, India (e-mail: drketandesai@hotmail.com).

J Neurosci Rural Pract 2021;12:470-477.

\begin{abstract}
Keywords

- BCTQ-Hindi version

- open carpal tunnel release

- external neurolysis of the median nerve

- long-term outcome
\end{abstract}

Background The effectiveness of open carpal tunnel release (OCTR) in treating carpal tunnel syndrome (CTS) is well known. However, the role of ancillary external neurolysis of the median nerve is not well-documented. The Boston carpal tunnel questionnaire (BCTQ) is a commonly used disease-specific outcome instrument for CTS, which is validated across major languages of the world. No such validated Hindi version of BCTQ exists.

Objectives To analyze and compare the long-term outcome in patients who underwent OCTR alone and OCTR with external neurolysis of the median nerve, using BCTQHindi version, while checking its validity.

Materials and Methods A retrospective, cross-sectional study was conducted at a tertiary care institute. The BCTQ was translated into Hindi language by a language expert. Eighty-four consecutive patients who underwent either unilateral/bilateral OCTR, with or without external neurolysis of the median nerve, between 2009 and 2019 were included in the study. Outcome analysis was done using BCTQ-Hindi version and patient satisfaction scoring. BCTQ-Hindi version was examined for statistical validity. Subgroup analysis of the outcome based on surgical technique (OCTR vs. OCTR with external neurolysis) used was carried out.

Results Response rate was $80.9 \%$. Total hands evaluated were 108. BCTQ-Hindi version showed statistical validity. Overall symptom severity score (SSS) and functional severity score (FSS) were $1.14 \pm 0.4$ and $1.12 \pm 0.35$, respectively. Subgroup analysis of outcome revealed statistically significant results in favor of OCTR with external neurolysis of the median nerve.

Conclusions BCTQ-Hindi version is statistically validated. OCTR with external neurolysis of the median nerve is a promising avenue in surgical management of CTS. Further prospective studies are warranted. published online March 13, 2021
DOI https://doi.org/

10.1055/s-0041-1723100 ISSN 0976-3147. (c) 2021. Association for Helping Neurosurgical Sick People.

This is an open access article published by Thieme under the terms of the Creative Commons Attribution-NonDerivative-NonCommercial-License, permitting copying and reproduction so long as the original work is given appropriate credit. Contents may not be used for commercial purposes, or adapted, remixed, transformed or built upon. (https://creativecommons.org/licenses/by-nc-nd/4.0/).

Thieme Medical and Scientific Publishers Pvt. Ltd. A-12, 2nd Floor, Sector 2, Noida-201301 UP, India 


\section{Key-Messages}

BCTQ-Hindi version is statistically validated. OCTR with external neurolysis of the median nerve is a promising avenue in surgical management of CTS.

\section{Introduction}

Carpal tunnel syndrome (CTS) is the most common clinically encountered entrapment neuropathy, resulting from compression of the median nerve., ${ }^{1,2}$ Although the exact cause and pathogenesis of CTS are still unclear, it is found related to numerous risk factors like size of the carpal tunnel; pregnancy; occupations involving repeated exposure of the hand and wrist to high pressure or high force or vibrating tools; and systemic comorbidities like obesity, thyroid dysfunction, diabetes mellitus, and rheumatoid arthritis., ${ }^{3,4}$ The clinical manifestations include pain and paresthesias in the hand and digits, along the median nerve distribution, as well as paralysis and wasting of the hand muscles. Diagnosis is based on clinical symptoms, electrophysiological testing and, more recently, ultrasonography of the median nerve. ${ }^{5}$ The patients with milder form of CTS can be managed with conservative measures like wrist support and steroid injections. However, in moderate or severe cases, surgical carpal tunnel release (CTR) has shown the best results. ${ }^{4,5}$ CTR is called primary when done for the first time in cases of CTS. Recurrent CTS is treated via revision/secondary CTR. While the literature has shown equivalent efficacies between endoscopic and open releases, open carpal tunnel release (OCTR) is still recognized as the gold standard for carpal tunnel decompression. ${ }^{6,7}$

The pathophysiology of CTS involves a combination of physiological/pathological processes, leading to chronic compression and ischemic damage to the median nerve. This results in the median nerve developing adhesions and losing its ability to "glide freely" during movements of the wrist joint within the carpal tunnel. ${ }^{8}$ To counter such pathological processes that might result in the persistence of symptoms post OCTR alone, surgeons in 1990s started probing into the role of ancillary procedures in OCTR, like internal neurolysis, epineurotomy, tenosynovectomy, and tendon transfers. ${ }^{9-11}$ Multiple randomized controlled trials over the past three decades have shown no additional benefits of internal neurolysis and epineurotomy; hence, they are no longer used in clinical practice. ${ }^{12,13}$ On the contrary, external neurolysis in OCTR remains an underrated and poorly evaluated ancillary technique.

In recent years, self-administered and standardized questionnaires, evaluating outcomes of concern to the patients are increasingly in clinical practice. The Boston carpal tunnel questionnaire (BCTQ) is one such commonly used standardized questionnaire, evaluating symptom severity and functional status in CTS. ${ }^{14}$ This questionnaire has been translated into many major languages of the world, and it is found to be valid and reliable. ${ }^{15-19}$ Although Mody et al published a paper on the use of a modified BCTQ for Hindi speaking population, no readily usable and validated Hindi version of BCTQ exists to date. ${ }^{20}$ Hence, our study aims to translate and statistically validate BCTQ-Hindi version, and apply it in studying long-term outcomes in patients who have undergone OCTR with or without external neurolysis of the median nerve.

\section{Materials and Methods}

\section{Study Design}

This is a retrospective, cross-sectional study including all the consecutive OCTR cases done by the senior author between 2009 to 2019 at P D Hinduja Hospital, Mumbai. The study group included all the living patients who had undergone OCTR for unilateral/bilateral CTS, with or without external neurolysis of the median nerve, as of June 1, 2020. Another prerequisite for patient inclusion was the ability to read Hindi language and complete a written questionnaire. An informed valid consent was taken from all the eligible patients who were willing to be a part of this study. At our institute, CTR is offered only to moderate or severe CTS cases (grading as per American Association of Neuromuscular and Electrodiagnostic Medicine; AANEM ${ }^{21}$ ) with failed conservative management after 4 to 6 weeks ( - Fig. 1).

\section{Surgical Techniques}

Patients in the study group received either a standard OCTR alone or a modified OCTR with an ancillary external neurolysis of the median nerve. A 2 to $3 \mathrm{~cm}$ palmar skin incision was used in both the procedures along the radial side of the ring finger. The incision was just short of wrist crease proximally and reaching the Kaplan cardinal line distally. Releasing of the transverse carpal ligament (TCL) in the longitudinal plane was done to achieve adequate decompression of the median nerve. ${ }^{22}$ Ancillary external neurolysis of the median nerve consisted of breaking down the adhesions and releasing of encapsulating scar tissue around the nerve, to restore nerve's ability to "glide freely" during wrist joint movements. The deep fascia of the forearm in the region of the wrist was also divided along with the TCL, as it may sometimes also act as a compressing force. - Fig. $\mathbf{2}$ shows the procedural steps of OCTR with external neurolysis of the median nerve. All CTRs done before 2014 received OCTR alone. Since 2014, the senior author started including an ancillary external neurolysis of the median nerve along with all the OCTRs, based on the encouraging results of external neurolysis seen in other peripheral neuropathies. Majority OCTRs were done under local anesthesia. Mild sedation or occasional short general anesthesia (GA) was used in anxious patients, and those undergoing external neurolysis. No tourniquets were used in any of the OCTRs. Simultaneous or staged OCTRs were offered to bilaterally symptomatic CTS patients.

\section{BCTQ-Hindi Version}

The BCTQ assesses CTS-specific impairments through its two scales: 11-item symptom severity scale (SSS) and 8-item functional status scale (FSS). ${ }^{14}$ Each item, across both the scales, has five possible response options ranging from 1 to 5 with 1 being no concerns and 5 being the 


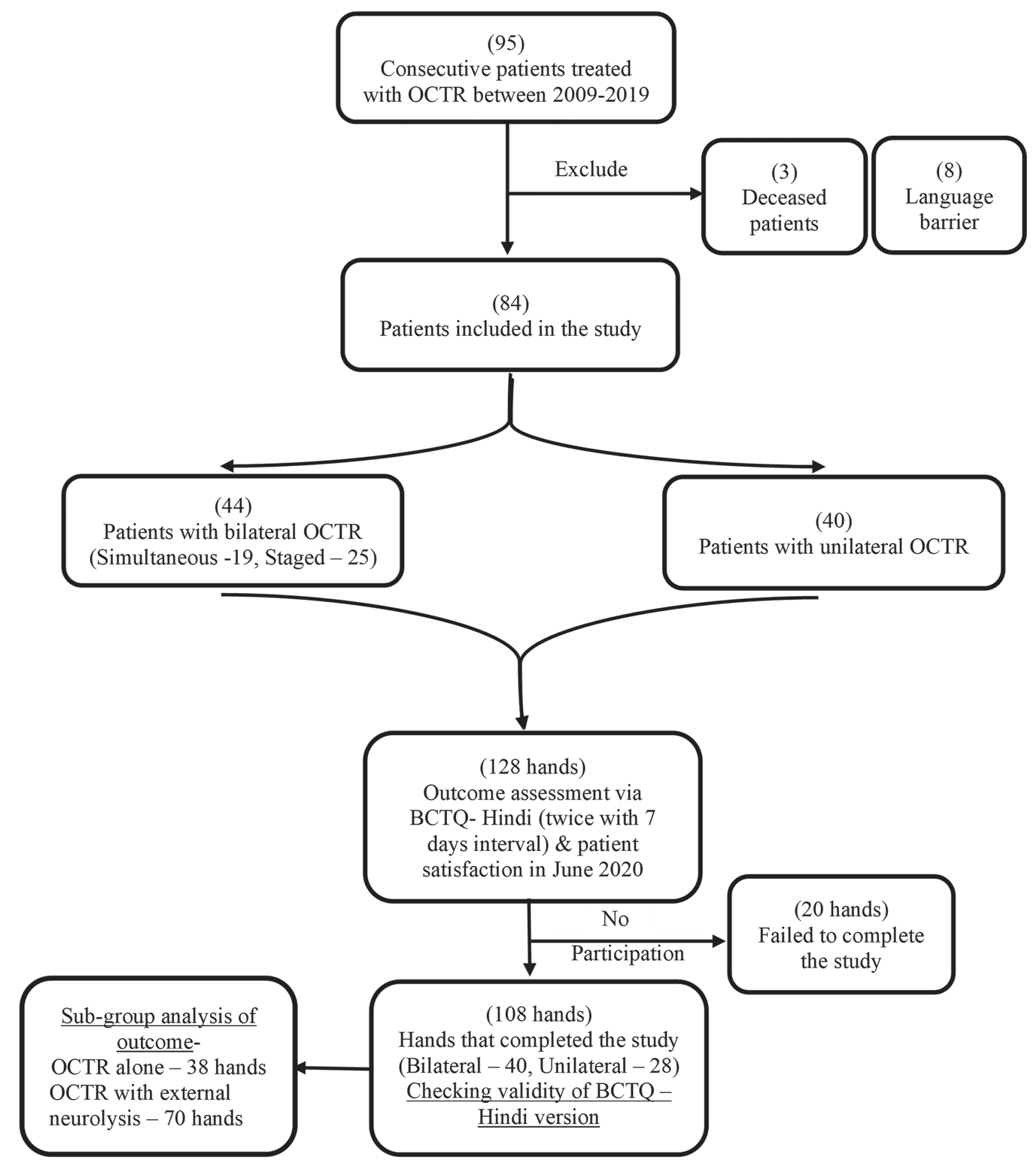

Fig. 1 Flowchart depicting the study procedure. OCTR, open carpal tunnel release, BCTQ, Boston carpal tunnel questionnaire.

worst status. ${ }^{23}$ Final scoring for each scale (SSS and FSS) is obtained by taking an average of all the items in that particular scale. An SSS or FSS score of $\geq 2$ is considered as an unfavorable outcome, as this had been used in previously published studies. ${ }^{14,24-26}$ The BCTQ was translated into the Hindi language, according to the accepted rules 

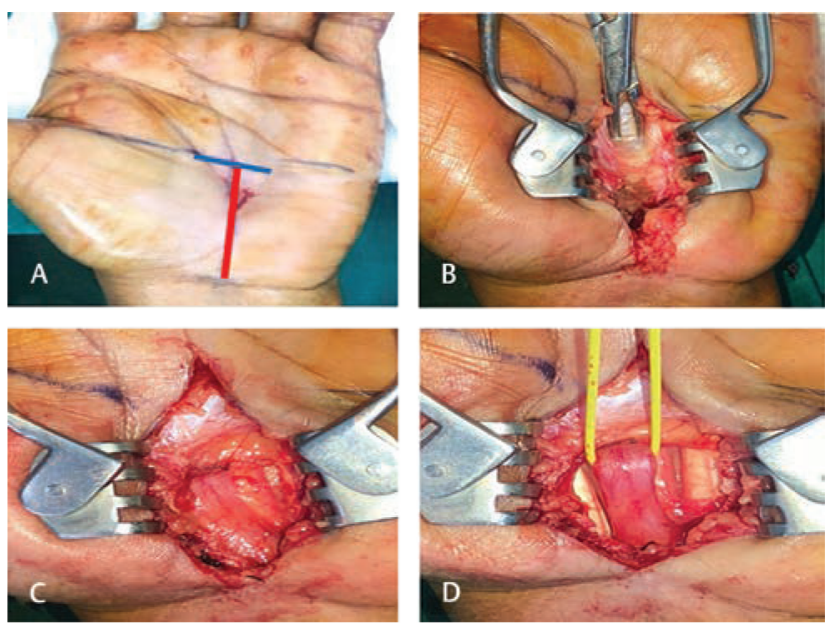

Fig. 2 Procedural steps of open carpal tunnel release (OCTR) with median nerve neurolysis. (A) 2 to $3 \mathrm{~cm}$ skin incision (red line) taken along the radial border of the ring finger, just short of wrist crease proximally, and reaching the Kaplan cardinal line distally (blue line); (B) releasing of the transverse carpal ligament (TCL); (C) post TCL release-median nerve seen with surrounding adhesions; (D) postmedian nerve external neurolysis (yellow tag).

of forward-backward translation by a language expert. ${ }^{27}$ (-Fig. 3).

\section{Study Procedure and Statistical Analysis}

Out of 95 consecutive patients who underwent either unilateral/bilateral OCTR between 2009 and 2019, 84 patients satisfied the inclusion criteria and were included in the study. We analyzed the number of hands/cases operated rather than the number of patients for the sake of accuracy. - Fig. 1 summarizes the study procedure carried out in June 2020. Outcome assessment via BCTQ-Hindi version (twice with 7 days interval in June 2020) and patient satisfaction score (3-point Likert scale; patients rather than hands/ cases used to prevent patient bias) was carried out via phone calls. Patient characteristics and clinical data were obtained from medical records section.

BCTQ data obtained from the study was used to examine its own statistical validity. Pearson correlation coefficient $(r)$ was used for test-retest analysis ( $r=0$, no correlation; $r=1$, perfect correlation; $r>0.7$ strong correlation) ${ }^{28,29}$ Internal consistencies were measured using Cronbach's alpha $(\alpha)$. An $\alpha$ value of 0.8 to 0.9 and $\geq 0.9$ was interpreted as good and excellent consistencies, respectively. The Fisher exact test and Student t-test were used to calculate statistical significance ( $p$ value $<0.05$, significant result). Statistical analysis was carried out using SPSS software (version 23 for Windows).

\section{Results}

\section{Demographics}

The study group included 84 patients accounting for 128 hands/cases operated. BCTQ-Hindi version questionnaire was telephonically administered to the patients, twice with 7 days interval, by two different authors. Patient satisfaction score was also obtained simultaneously by the authors. Response rate was $80.9 \%$. Demographics and clinical data of those patients or hands/cases who completed the study have been tabulated in - Table 1. Mean age of the patients at the time of outcome analysis was $57.94 \pm 10.9$ years. Female to male ratio was 5.2:1. Commonest comorbidities reported among patients were hypothyroidism (25\%), diabetes (20.5\%), and rheumatoid/gouty arthritis (5.9\%). Common presenting symptoms in hands/cases were pain (73.1\%), paresthesias and numbness (63\%), hand weakness (25.9\%), and abductor pollicis brevis (APB) atrophy (12.9\%). Majority of hands/cases who underwent OCTR surgeries belonged to American Association of Neuromuscular and Electrodiagnostic Medicine (AANEM) grade of severe CTS (85.2\%). Bilateral OCTR and unilateral OCTR was done in $58.8 \%$ and $41.2 \%$ of patients, respectively. All hands/cases in the study had undergone primary OCTR. There were no reported intra- or postoperative complications, except for transient (2-3 months) scar tenderness in about $12 \%$ of hands/cases. Mean outpatient follow-ups post OCTR was 7.4 months.

\section{Proof of Validity of BCTQ-Hindi Version}

The overall BCTQ-Hindi version scores are as follows: SSS-1.14 \pm 0.4 and FSS-1.12 \pm 0.35 . Both SSS and FSS scales showed excellent/good internal consistency ( $\alpha$ values are 0.9 and 0.81 , respectively). Test-retest analysis showed good reproducibility ( $r$ for SSS $=0.72 ; r$ for FSS $=0.78$ ). Both these facts present a good evidence to suggest the validity of BCTQHindi version.

\section{Outcome Analysis}

The mean overall BCTQ-Hindi version scores suggest a very good long-term outcome from OCTR with or without external neurolysis (SSS $=1.14 \pm 0.4 ;$ FSS $=1.12 \pm 0.35$ ). There was an unfavorable symptom severity score $(\geq 2)$ in seven $(6.5 \%)$ and an unfavorable function severity score $(\geq 2)$ in five (4.6\%) hands/cases. Persistence of numbness, although in a decreased severity, was seen in seven (6.48\%) hands/cases. Mild hand grip weakness persisted in four (3.7\%) hands/cases. No recurrence of symptoms seen in any of the hands/cases that had become asymptomatic post OCTR. Perfect/normal score of SSS and FSS scale $(=1)$ was seen in $81(75 \%)$ hands/cases.

On doing a factor-based subgroup analysis of the outcome with respect to surgical technique used, it was found that hands/ cases who had undergone OCTR with external neurolysis of the median nerve fared well compared to those who had undergone OCTR alone. Mean BCTQ-Hindi version scores for groups-OCTR alone and OCTR with external neurolysis of the median nerve were SSS $-1.29 \pm 0.62 /$ FSS $-1.25 \pm 0.54$ and SSS $-1.06 \pm 0.13 /$ FSS$1.05 \pm 0.11$, respectively ( $p$ value $=0.0000$, student $t$-test $)$. All the hands/cases with an unfavorable ( $\geq 2$ ) SSS or FSS in our study belonged to the OCTR alone group ( - Table 2 ).

\section{Patient Satisfaction}

Patients were subjected to additional three questions based on their satisfaction with the surgery and its outcome (3-point Likert scale). Overall, 94.1\% (64 out of 68) 


\section{बोस्टन कार्पल टनेल सिंड्रोम प्रश्नावली (बीसीटीक्य)}

अ) लक्षण गंभीरता / लक्षणों की गंभीरता का स्केल (११ प्रश्न / चीज़ें)

\begin{tabular}{|c|c|c|c|c|c|}
\hline $\begin{array}{l}\text { निम्नलिखित प्रश्न पिछले २ हफ़्तों के दौरान सामान्यत: } \\
\text { २४ घंटों की अवधि के लिए देखे गए आपके लक्षणों के } \\
\text { बारे में हैं }\end{array}$ & ? & २ & 3 & 8 & $\varphi$ \\
\hline $\begin{array}{l}\text { ९.रात में आपके हाथ या कलाई में होने वाला दर्द कितना } \\
\text { गंभीर है? }\end{array}$ & $\begin{array}{l}\text { कोई } \\
\text { (दर्द) नहीं }\end{array}$ & सौम्य & मध्यम & गंभीर & $\begin{array}{l}\text { बहुत/अति } \\
\text { गंभीर }\end{array}$ \\
\hline $\begin{array}{l}\text { २. पिछले दो हफ्तो में सामान्य रात के दौरान हाथ या } \\
\text { कलाई में होनेवाले दर्द के कारण आप नींद से कितनी } \\
\text { बार जाग गये थे? }\end{array}$ & कभी नहीं & $\begin{array}{l}\text { एक } \\
\text { बार }\end{array}$ & $\begin{array}{l}\text { २-3 } \\
\text { बार }\end{array}$ & $\begin{array}{l}\text { 8-4 } \\
\text { बार }\end{array}$ & $\begin{array}{l}\varphi \text { से अधिक } \\
\text { बार }\end{array}$ \\
\hline $\begin{array}{l}\text { 3.क्या सामान्य रुप से दिन के दौरान आपके हाथ या } \\
\text { कलाई में दर्द होता है? }\end{array}$ & $\begin{array}{l}\text { कोई (दर्द) } \\
\text { नहीं }\end{array}$ & सौम्य & मध्यम & गंभीर & $\begin{array}{l}\text { बहुत/अति } \\
\text { गंभीर }\end{array}$ \\
\hline $\begin{array}{l}\text { ४.आपको दिन के दौरान कितनी बार हाथ या कलाई में } \\
\text { दर्द होता है? }\end{array}$ & कभी नहीं & $\begin{array}{l}\text { १-२ } \\
\text { बार }\end{array}$ & $\begin{array}{l}\text { 3-4 } \\
\text { बार }\end{array}$ & $\begin{array}{l}\varphi \text { से } \\
\text { अधिक बार }\end{array}$ & $\begin{array}{l}\text { अविरत / } \\
\text { निरंतर दर्द }\end{array}$ \\
\hline $\begin{array}{l}\text { 9. दिन के दौरान दर्द का एपिसोड औसतन कितने समय } \\
\text { तक रहता है? }\end{array}$ & कभी नहीं & $\begin{array}{l}<१ \circ \\
\text { मिनट }\end{array}$ & $\begin{array}{l}\text { १०-६० } \\
\text { मिनट }\end{array}$ & $>\varepsilon \circ$ मिनट & $\begin{array}{l}\text { अविरत/ } \\
\text { निरंतर दर्द }\end{array}$ \\
\hline $\begin{array}{l}\text { ६.क्या आपके हाथ में सुन्नता (संवेदना महसूस न होना) } \\
\text { है? }\end{array}$ & $\begin{array}{l}\text { कोई (सुन्नता) } \\
\text { नहीं }\end{array}$ & सौम्य & मध्यम & गंभीर & $\begin{array}{l}\text { बहुत/अति } \\
\text { गंभीर }\end{array}$ \\
\hline ७.क्या आपके हाथ या कलाई में कमजोरी है? & $\begin{array}{l}\text { कोई } \\
\text { (कमजोरी) नहीं }\end{array}$ & सौम्य & मध्यम & गंभीर & $\begin{array}{l}\text { बहुत/अति } \\
\text { गंभीर }\end{array}$ \\
\hline ८.क्या आपके हाथ में झुनझुनी की संवेदनाएं हैं? & $\begin{array}{l}\text { कोई (झुनझुनी) } \\
\text { नहीं }\end{array}$ & सौम्य & मध्यम & गंभीर & $\begin{array}{l}\text { बहुत/अति } \\
\text { गंभीर }\end{array}$ \\
\hline $\begin{array}{l}\text { ९.सुन्नता (संवेदना महसूस न होना) या झुनझुनी रात में } \\
\text { कितनी गंभीर है? }\end{array}$ & $\begin{array}{l}\text { कोई (सुन्नता } \\
\text { या झुनझुनी) } \\
\text { नहीं }\end{array}$ & सौम्य & मध्यम & गंभीर & $\begin{array}{l}\text { बहुत/अति } \\
\text { गंभीर }\end{array}$ \\
\hline $\begin{array}{l}\text { १०. पिछ्छे दो हफ्तो में सामान्य रात के दौरान हाथ में } \\
\text { होनेवाले सुन्नता या झुनझुनी के कारण आप नींद से } \\
\text { कितनी बार जाग गये थे? }\end{array}$ & कभी नहीं & $\begin{array}{l}\text { एक } \\
\text { बार }\end{array}$ & $\begin{array}{l}\text { २-3 } \\
\text { बार }\end{array}$ & $\begin{array}{l}\text { 8-9 } \\
\text { बार }\end{array}$ & $\begin{array}{l}9 \text { से अधिक } \\
\text { बार }\end{array}$ \\
\hline $\begin{array}{l}\text { १९.क्या आपको चाबी या कलम/पेन जैसी छोटी वस्तुओं } \\
\text { को पकड़ने और उनका उपयोग करने में कठिनाई है? }\end{array}$ & कभी नहीं & सौम्य & मध्यम & गंभीर & $\begin{array}{l}\text { बहुत/अति } \\
\text { गंभीर }\end{array}$ \\
\hline
\end{tabular}

ब) कार्यात्मक स्थिति का स्केल (८ चीज़ें / गतिविधियाँ)

\begin{tabular}{|c|c|c|c|c|c|}
\hline $\begin{array}{l}\text { पिछले दो हफ़्तों के दौरान सामान्य दिन पर हाथ और } \\
\text { कलाई के लक्षणों के कारण नीचे सूचीबद्ध की गयी } \\
\text { गतिविधियों को करने में आपको कठिनाई हुई? }\end{array}$ & $\begin{array}{l}\text { कोई } \\
\text { कठिनाई } \\
\text { नहीं }\end{array}$ & $\begin{array}{l}\text { सौम्य } \\
\text { कठिनाई }\end{array}$ & $\begin{array}{l}\text { मध्यम } \\
\text { कठिनाई }\end{array}$ & $\begin{array}{l}\text { गंभीर } \\
\text { कठिनाई }\end{array}$ & $\begin{array}{l}\text { बहुत/अति गंभीर } \\
\text { कठिनाई (कोई } \\
\text { गतिविधि नहीं कर } \\
\text { सकता/सकती) }\end{array}$ \\
\hline १. लिखना & ? & २ & 3 & 8 & $\varphi$ \\
\hline २. कपडों के बटन्स लगाना & \& & २ & 3 & 8 & $\varphi$ \\
\hline 3. पढ़ते समय किताब पकडना & q & २ & 3 & ४ & $\varphi$ \\
\hline ४. टेलीफोन के हैंडल को पकडना & $?$ & २ & 3 & 8 & $\varphi$ \\
\hline ५. जार / मर्तबान खोलना & $\xi$ & २ & 3 & 8 & 9 \\
\hline ६. घर के काम करना & $?$ & २ & 3 & 8 & $\varphi$ \\
\hline ७. किराने की थैलियों को ले जाना & ? & २ & 3 & 8 & $\varphi$ \\
\hline ८. स्नान करना और कपड़े परिधान करना & $\xi$ & २ & 3 & 8 & $\varphi$ \\
\hline
\end{tabular}

Fig. 3 Boston carpal tunnel questionnaire (BCTQ)-Hindi version used in the study. 
Table 1 Demographics of patients in our study

\begin{tabular}{|c|c|}
\hline Total patients evaluated in the study & $n=68$ \\
\hline Age in years, mean (SD) & $57.94(10.90)$ \\
\hline Sex ratio (female: male) & 5.2: 1 \\
\hline \multicolumn{2}{|l|}{ Hand dominance, no. (\%) } \\
\hline Left & $7(10.3)$ \\
\hline Right & $59(89.7)$ \\
\hline Ambidextrous & $0(0)$ \\
\hline \multicolumn{2}{|l|}{ Occupation, no. (\%) } \\
\hline Homemaker & $33(48.5)$ \\
\hline Office worker & $23(33.8)$ \\
\hline Retired & $8(11.8)$ \\
\hline Unemployed & $4(5.9)$ \\
\hline \multicolumn{2}{|l|}{ Comorbidities, no. (\%) } \\
\hline Diabetes & $14(20.5)$ \\
\hline Hypothyroidism & $17(25)$ \\
\hline Rheumatoid/gouty arthritis & $4(5.9)$ \\
\hline \multicolumn{2}{|l|}{ Involvement-bilateral/unilateral OCTR } \\
\hline $\begin{array}{l}\text { Bilateral OCTR } \\
\text { (simultaneous surgery-17, staged surgery-23) }\end{array}$ & $40(58.8)$ \\
\hline $\begin{array}{l}\text { Unilateral OCTR } \\
\text { (left-13, right-15) }\end{array}$ & $28(41.2)$ \\
\hline Total hands/cases evaluated in the study & $n=108$ \\
\hline \multicolumn{2}{|l|}{ Symptoms, no. (\%) } \\
\hline Paresthesias & $79(73.1)$ \\
\hline Numbness & $68(63)$ \\
\hline Pain & $58(53.7)$ \\
\hline Hand weakness & $28(25.9)$ \\
\hline APB atrophy & $14(12.9)$ \\
\hline \multicolumn{2}{|l|}{ AANEM grading, no. (\%) } \\
\hline Mild CTS & $2(1.8)$ \\
\hline Moderate CTS & $14(13)$ \\
\hline Severe CTS & $92(85.2)$ \\
\hline \multicolumn{2}{|l|}{ Surgical technique, no. (\%) } \\
\hline OCTR alone & $38(35.2)$ \\
\hline OCTR with external neurolysis & $70(64.8)$ \\
\hline Mean follow-up periods, mean in months (SD) & $7.4(3.8)$ \\
\hline
\end{tabular}

Abbreviations: AANEM, American Association of Neuromuscular and Electrodiagnostic Medicine; APB, abductor pollicis brevis; OCTR, open carpal tunnel release; SD, standard deviation. of patients were satisfied with their surgery, 88.2\% (60 out of 68) said they would undergo the surgery again (retrospective consent) if they had a choice, and $82.4 \%$ (56 out of 68) would recommend the surgery to their friends and family.

\section{Discussion}

According to the results of this study, BCTQ-Hindi version is statistically validated and is successfully used in studying the long-term outcome in patients post OCTR. Since BCTQ is a simple, self-administered questionnaire which can be completed in less than 10 minutes, it can be used routinely on an outpatient basis. A recent systematic review published by Mehta et al regarding BCTQ's measurement properties has greatly reinforced its evidence-based use in clinical practice. ${ }^{23}$ Our BCTQ-Hindi version's good internal consistencies and reproducibility are comparable to the most published validation studies in major languages of the world. ${ }^{16-19}$

Good long-term outcome noted in the present study, with a persistence rate of $6.48 \%$ and no recurrences, is in accordance with the existing literature..$^{24-26,30}$ Although $85.2 \%$ of the operated hands/cases had severe CTS, complete recovery (SSS and FSS = 1) was seen in $75 \%$ hands/ cases post OCTR. Hence, our study supplements the view of those studies which have previously reported a significant reduction in symptoms after CTR, even in severe cases. ${ }^{26,31,32}$ The overall results of surgery are rewarding, and patients show a dramatic relief in pain as well as paresthesia, and the motor weakness also improves over time.

Although many surgical techniques have been used to treat CTS in recent times, such as the miniopen CTR or the endoscopic CTR, we still prefer the standard OCTR technique $(2-3 \mathrm{~cm}$ incision), as it provides us the ability to examine the contents of the carpal tunnel, decreases the risk of inadvertent nerve injuries, and increases the probability of complete TCL release. ${ }^{6}$ Zero intra- or postoperative complications reported in our study substantiates the robust safety profile of the standard OCTR. Our wide-awake (local anesthesia) and no tourniquet policy for OCTR received strong support from a recent meta-analysis published by Olaiya et al. ${ }^{33}$ The paper reported that "tourniquet use causes significantly more pain with no added

Table 2 Surgical technique-based outcome assessment via BCTQ-Hindi version

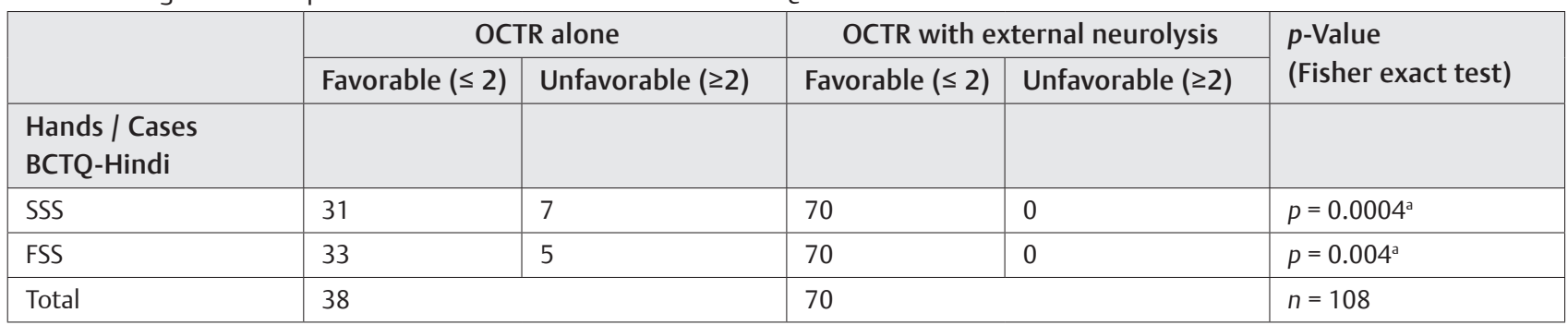

Abbreviations: BCTQ, Boston carpal tunnel questionnaire; FSS, functional severity score; OCTR, open carpal tunnel release; SSS, symptom severity score.

${ }^{a}$ Statistically significant results. 
clinical benefit as compared with using a wide awake, no tourniquet approach in CTR."

The main finding of the present study was that the long-term outcome with external neurolysis in OCTR was significantly better than with OCTR alone. A possible explanation for this could be the restoration of physiologic nerve gliding in cases undergoing external neurolysis of the median nerve, and the resulting reversal in the direct or indirect compression-induced changes in the affected nerve. ${ }^{8,9,34}$ Studies have also reported that timely reversal of compression-induced nerve changes would result in near complete recovery. ${ }^{35}$

The ancillary procedures like internal neurolysis and epineurotomy are no longer used routinely in the management of CTS. ${ }^{11}$ Similarly, tenosynovectomy in CTS is restricted to those patients with underlying rheumatologic/inflammatory factors or incidental gross synovitis noted at the surgery. ${ }^{10}$ These practices stem from the poor safety profile of such procedures. On the contrary, external neurolysis is a very simple and relatively safe ancillary procedure that has proven benefits in a variety of peripheral neuropathies secondary to adhesions, as has been reported in the literature. ${ }^{34,36-38}$ Although many peripheral nerve surgeons incorporate external neurolysis of the median nerve in their carpal tunnel decompression, a very limited body of clinical evidence exists to justify the same.

In the available literature, only a couple of articles have tried to analyze the role of external neurolysis of the median nerve in CTR. Duclos et al reported the outcome of "extensive external neurolysis of the median nerve (from distal forearm to across the carpal tunnel) without a vascularized flap" in cases of recurrent CTS. ${ }^{39}$ They concluded that the extensive external neurolysis alone successfully established normal gliding of the median nerve, and a more invasive surgical procedure involving vascularized flap is not justified. Sri-Ram et al compared the results of simple CTR and CTR with external neurolysis of the median nerve in cases of lysosomal storage disorders in pediatric population..$^{40}$ The outcome measured using a neurophysiological criterion showed no added benefit from external neurolysis. To the best of our knowledge, no other article has ever evaluated the role of external neurolysis in primary OCTR, and using measures like a long-term outcome or a self-administered questionnaire.

\section{Limitations}

Despite statistically validating the BCTQ-Hindi version, the relatively small sample size, post OCTR status, and questionable representativeness of the study population undermine the significance of our results. Study groups used to compare the outcomes based on surgical techniques were not age-, sex- or electrodiagnostically matched to provide significant conclusions. Further prospective studies should be done that compare patient outcomes following both the surgical techniques in a matched study group.

\section{Conclusion}

Good internal consistencies and reproductivity of BCTQHindi version have statistically validated the same. Good long-term outcome is seen in CTS undergoing OCTR. The use of external neurolysis of the median nerve in OCTR is a promising avenue that must be further explored using prospective randomized studies. All patients with CTS should undergo periodic symptom and functional severity assessment. And this BCTQ-Hindi version can be used in clinical practice for native Hindi speaking patients.

\section{Conflict of Interest}

None declared.

\section{Acknowledgements}

The authors thank Dr. Anandini Kshirsagar for her assistance with the translation process of BCTQ into the Hindi language.

\section{References}

1 Atroshi I, Gummesson C, Johnsson R, Ornstein E, Ranstam J, Rosén I. Prevalence of carpal tunnel syndrome in a general population. JAMA 1999;282(2):153-158

2 Aroori S, Spence RA. Carpal tunnel syndrome. Ulster Med J 2008;77(1):6-17

3 Yunoki M, Kanda T, Suzuki K, Uneda A, Hirashita K, Yoshino K. Importance of recognizing carpal tunnel syndrome for neurosurgeons: a review. Neurol Med Chir (Tokyo) 2017;57(4):172-183

4 Desai K. Carpal tunnel syndrome: the lessons learnt and the points often overlooked in its management. Neurol India 2018;66(3):674-675

5 Padua L, Coraci D, Erra C, et al. Carpal tunnel syndrome: clinical features, diagnosis, and management. Lancet Neurol 2016;15(12):1273-1284

6 Chen L, Duan X, Huang X, Lv J, Peng K, Xiang Z. Effectiveness and safety of endoscopic versus open carpal tunnel decompression. Arch Orthop Trauma Surg 2014;134(4):585-593

7 Kaplan J, Roth C, Melillo A, Koko E, Fuller D, Perry A. Analysis of surgical options for patients with bilateral carpal tunnel syndrome. J Orthop 2020;22:86-89

8 Millesi H, Zöch G, Rath T. The gliding apparatus of peripheral nerve and its clinical significance. Ann Chir Main Memb Super 1990;9(2):87-97

9 Millesi H, Rath T, Reihsner R, Zoch G. Microsurgical neurolysis: its anatomical and physiological basis and its classification. Microsurgery 1993;14(7):430-439

10 Corradi M, Paganelli E, Pavesi G. Internal neurolysis and flexor tenosynovectomy: adjuncts in the treatment of chronic median nerve compression at the wrist in hemodialysis patients. Microsurgery 1989;10(3):248-250

11 Ting J, Weiland AJ. Role of ancillary procedures in surgical management of carpal tunnel syndrome: epineurotomy, internal neurolysis, tenosynovectomy, and tendon transfers. Hand Clin 2002;18(2):315-323

12 Mackinnon SE, McCabe S, Murray JF, et al. Internal neurolysis fails to improve the results of primary carpal tunnel decompression. J Hand Surg Am 1991;16(2):211-218

13 Chapell R, Coates V, Turkelson C. Poor outcome for neural surgery (epineurotomy or neurolysis) for carpal tunnel syndrome compared with carpal tunnel release alone: a meta-analysis 
of global outcomes. Plast Reconstr Surg 2003;112(4):983-990, discussion 991-992

14 Levine DW, Simmons BP, Koris MJ, et al. A self-administered questionnaire for the assessment of severity of symptoms and functional status in carpal tunnel syndrome. J Bone Joint Surg Am 1993;75(11):1585-1592

15 Sezgin $M$, Incel NA, Serhan S, Çamdeviren $H$, As I, Erdoğan C. Assessment of symptom severity and functional status in patients with carpal tunnel syndrome: reliability and functionality of the Turkish version of the Boston Questionnaire. Disabil Rehabil 2006;28(20):1281-1285

16 Bougea A, Zambelis T, Voskou P, et al. Reliability and validation of the greek version of the boston carpal tunnel questionnaire. Hand (N Y) 2018;13(5):593-599

$17 \mathrm{Kim}$ JK, Lim HM. The Korean version of the carpal tunnel questionnaire. Cross cultural adaptation, reliability, validity and responsiveness. J Hand Surg Eur Vol 2015;40(2):200-205

18 Atroshi I, Johnsson R, Sprinchorn A. Self-administered outcome instrument in carpal tunnel syndrome. Reliability, validity and responsiveness evaluated in 102 patients. Acta Orthop Scand 1998;69(1):82-88

19 Trybus M, Koziej M, Belka M, Bednarek M, Banach M. The Polish version of the Boston carpal tunnel questionnaire: associations between patient-rated outcome measures and nerve conduction studies. J Plast Reconstr Aesthet Surg 2019;72(6):924-932

20 Mody GN, Anderson GA, Thomas BP, Pallapati SCR, Santoshi JA, Antonisamy B. Carpal tunnel syndrome in Indian patients: use of modified questionnaires for assessment. J Hand Surg Eur Vol 2009;34(5):671-678

21 Stevens JC; American Association of Electrodiagnostic Medicine. AAEM minimonograph \#26: the electrodiagnosis of carpal tunnel syndrome. Muscle Nerve 1997;20(12):1477-1486

22 Rodner C, Katarincic J. Open carpal tunnel release. Tech Orthop 2006;21:3-11

23 Mehta SP, Weinstock-Zlotnick G, Akland KL, Hanna MM, Workman KJ. Using carpal tunnel questionnaire in clinical practice: a systematic review of its measurement properties. J Hand Ther 2020;33(4):493-506 [Internet]

24 Katz JN, Keller RB, Simmons BP, et al. Maine carpal tunnel study: outcomes of operative and nonoperative therapy for carpal tunnel syndrome in a community-based cohort. J Hand Surg Am 1998;23(4):697-710

25 Louie D, Earp B, Blazar P. Long-term outcomes of carpal tunnel release: a critical review of the literature. Hand (N Y) 2012;7(3):242-246

26 Tang CQY, Lai SWH, Tay SC. Long-term outcome of carpal tunnel release surgery in patients with severe carpal tunnel syndrome. Bone Joint J 2017;99-B(10):1348-1353
27 Hall DA, Zaragoza Domingo S, Hamdache LZ, et al; International Collegium of Rehabilitative Audiology and TINnitus Research NETwork. A good practice guide for translating and adapting hearing-related questionnaires for different languages and cultures. Int J Audiol 2018;57(3):161-175

28 Bland JM, Altman DG. Statistical methods for assessing agreement between two methods of clinical measurement. Lancet 1986;1(8476):307-310

29 Feinstein AR. Clinimetrics. New Haven: Yale University Press; 1987

30 De Kleermaeker FGCM, Meulstee J, Bartels RHMA, Verhagen WIM. Long-term outcome after carpal tunnel release and identification of prognostic factors. Acta Neurochir (Wien) 2019;161(4):663-671

31 Nolan WB III, Alkaitis D, Glickel SZ, Snow S. Results of treatment of severe carpal tunnel syndrome. J Hand Surg Am 1992;17(6):1020-1023

32 Iida J, Hirabayashi H, Nakase H, Sakaki T. Carpal tunnel syndrome: electrophysiological grading and surgical results by minimum incision open carpal tunnel release. Neurol Med Chir (Tokyo) 2008;48(12):554-559

33 Olaiya OR, Alagabi AM, Mbuagbaw L, McRae MH. Carpal tunnel release without a tourniquet: A systematic review and meta-analysis. Plast Reconstr Surg 2020;145(3):737-744

34 Swartz KR, Boland M, Fee DB. External neurolysis may result in early return of function in some muscle groups following brachial plexus surgery. Clin Neurol Neurosurg 2012;114(6):768-775

35 Mackinnon SE, Dellon AL, Hudson AR, Hunter DA. Chronic human nerve compression-a histological assessment. Neuropathol Appl Neurobiol 1986;12(6):547-565

36 Grandizio LC, Maschke S, Evans PJ. The management of persistent and recurrent cubital tunnel syndrome. J Hand Surg Am 2018;43(10):933-940

37 Warade AC, Jha AK, Pattankar S, Desai K. Radiation-induced brachial plexus neuropathy: A review. Neurol India 2019;67. (Supplement):S47-S52

38 Desai K, Warade AC, Jha AK, Pattankar S. Injection-related iatrogenic peripheral nerve injuries: Surgical experience of 354 operated cases. Neurol India 2019;67, (Supplement):S82-S91

39 Duclos L, Sokolow C. Management of true recurrent carpal tunnel syndrome: is it worthwhile to bring vascularized tissue? Chir Main 1998;17(2):113-117, discussion 118

40 Sri-Ram K, Vellodi A, Pitt M, Eastwood DM. Carpal tunnel syndrome in lysosomal storage disorders: simple decompression or external neurolysis? J Pediatr Orthop B 2007;16(3):225-228 